\title{
Digital Literacy and its Relevance to Comparative Education Researchers: Outcomes of SciVal Analytics
}

\author{
Oksana Chigisheva ${ }^{1,2^{\star}}$, Elena Soltovets ${ }^{3}$, Anna Dmitrova ${ }^{1}$, Anna G. Akhtyan ${ }^{4}$, Svetlana N. Litvinova ${ }^{5}$, \\ Yuliya V. Chelysheva ${ }^{6}$ \\ ${ }^{1}$ Department of Education and Pedagogical Sciences, Southern Federal University, Rostov-on-Don, RUSSIA \\ ${ }^{2}$ Chair on Global Education, Institute for Strategy of Education Development of the Russian Academy of Education, Moscow, \\ RUSSIA \\ ${ }^{3}$ Department of English for Humanities, Southern Federal University, Rostov-on-Don, RUSSIA \\ ${ }^{4}$ Faculty of Social Work, Russian State Social University, Moscow, RUSSIA \\ ${ }^{5}$ Zelenograd Branch - Institute of Business Administration of Moscow City Teacher Training University, Zelenograd, RUSSIA \\ ${ }^{6}$ Department of Sociocultural Activities and Arts, Moscow City Teacher Training University, Moscow, RUSSIA
}

Received 30 March 2021 - Accepted 8 June 2021

\begin{abstract}
Digitisation is a multidimensional phenomenon having direct and indirect impact on all aspects of human activity. The sphere of science and research, especially comparative education research, is being inevitably affected. The dizzying pace of socio-economic changes complicated by COVID19 pandemic made it obvious that we are dealing with the digitisation of shock, rather than phased, character. The article states the lack of serious scientific reflection on the currently witnessed "shock digitisation" of science, complicated with growing digital illiteracy of researchers. The latter is demonstrated through rigorous literature review and SciVal Scopus analytics. The article is concluded with the idea that the field of comparative education research requires future profound rethinking of assumptions and agenda priorities in several aspects. They include general qualification requirements for modern comparative education researcher and comparative research procedures, functional and digital literacy of comparativists, changes in their research career potentials and prospects.
\end{abstract}

Keywords: digitisation, shock digitisation, digital transformation of science, digital literacy, digital illiteracy, comparative education researcher, Open Science, SciVal Scopus analytics

\section{INTRODUCTION}

The 21st century is characterized by profound digitisation of all spheres of human activity directly affecting science and education. On the one hand it seems quite promising while, on the other hand, it is a very complicated process generating enough challenges (Kvon et al., 2018; Levina et al., 2019; Shinkevich et al., 2020; Yermilova et al., 2019). They demand quick adjustment to the new digital realia (Chigisheva, 2018). General requirements for research procedures, skills of modern researchers and the level of their functional and digital literacy are increasingly modified by external factors (Galchenko et al., 2020; Gimaliev et al., 2020; Tugun et al., 2020; Zyubina et al., 2019). They include internationalization and globalization of science and education, rapid development of Open Science, emergence of citizen science phenomenon, boom of digital pedagogy, etc. The mentioned factors also expand the range of research career opportunities. A. Toffler (1971) gives a vivid characteristic of the 21st century researchers. They live in the era of the information and postindustrial society and must be learning continuously: "The illiterate of the 21st century will not be those who cannot read and write, but those who cannot learn, unlearn, and relearn" (Toffler, 1971, p. 414). This idea of the philosopher is reflected in the European Charter for Researchers - The Code of Conduct for the Recruitment of Researchers (2005). The Charter specifies that "researchers at all career stages

(c) 2021 by the authors; licensee Modestum. This article is an open access article distributed under the terms and conditions of the Creative Commons Attribution License (http://creativecommons.org/licenses/by/4.0/). 


\section{Contribution to the literature}

- The study revealed the gaps in problematizing the "digital literacy" phenomenon in its relation to comparative education researchers facing the challenges of "shock digitisation" of science.

- The paper highlights key trends and contributors to modern "digital literacy" studies using the sets of metrics provided by SciVal analytics.

- The findings suggest the need for developing new digital skills emerging as a result of the growing requirements to comparative education researchers working in the context of "shock digitisation" and Open Science.

should seek to continually improve themselves by regularly updating and expanding their skills and competencies. This may be achieved by a variety of means including, but not restricted to, formal training, workshops, conferences and e-learning" (European Charter for Researchers - The Code of Conduct for the Recruitment of Researchers, 2005, p. 5). Hence, at present, continuous professional development gains special importance for researchers when it comes to digital literacy. It is crucial for researchers to understand what is going on in the "digital research world". Otherwise, they risk finding themselves in the so-called "Digital Middle Ages" (Chigisheva, 2018). This is particularly the case now, when external circumstances set the pace for transformations and progress. The COVID-19 pandemic is an example of the above, with its pronounced impact on the social and economic life worldwide. Clearly, the dizzying speed of digitisation suggests the shock nature of the process rather than its staged and smooth character. In the recently published work by the European scholars Leifert et al. (2020) "shock digitization" is associated with the accelerated transfer of all spheres of human life activity into virtual space. They also cover a wide range of challenges generated by this process, from the technology-related to cybersecurity issues. Within this new global challenge, the scientific and educational sphere is naturally involved, as well (Potapova et al., 2018). While the issues associated with the revolutionary implementation of digital technologies in education in the new environment have received a wide resonance and discussion (Ivanova \& Ivanov, 2020), systemic transformations in the field of science have not been conceptualized sufficiently.

These facts prioritize the following gaps of education research agenda: the lack of profound scientific reflection on the currently witnessed "shock digitisation" of science and escalating digital illiteracy of researchers (Soltovets et al., 2021). In the domain of comparative education, the latter works as a major stagnating factor impeding progress and thus significantly reducing the quality and efficiency of researcher's work.

\section{METHODOLOGY}

The purpose of the research is to probe on the conceptualization of the "digital literacy" phenomenon in terms of its interpretation, research and topicality trends in the field of comparative education. A large body of bibliometric data from Scopus database has been analyzed using the new generation analytic tools available from SciVal by Elsevier research intelligence. The analysis encompassed the publication records dated 2015-2020.

The assumptions of the study relied upon a multidimensional analysis of related publications addressing up-to-date research focus and approaches. The use of the in-built SciVal powerful metric values system allowed to trace existing and new emerging research trends reflecting growing interest to digitisation of science and the extent to which it is related to the trajectories of comparative education research. The process was much facilitated by SciVal search features which helped to obtain a more complete picture of the scholars' performance and institutions' activities. The userfriendly mechanism of visualization helped to combine different sets of metrics, including scholarly output, citation impact, views count, citation count, fieldweighted citation impact, prominence percentile (Research Metrics Guidebook, 2019).

The metric of scholarly output has revealed research frontier institutions in the field of comparative education. Moreover, it helped to visualize the picture of location-specific publications authored by the scholars affiliated with the most active institutions in the topic, evidencing the distribution of publications worldwide. The analysis of publication performance metric outlined the main topical trends dominating digital literacy related publications indexed by SciVal analytics. Key words and phrases were also taken as units of analysis to evaluate the field range of studies addressing the issues of "digital literacy", as well as the visibility of publication activity of the most active researchers in the domain of education. The outcomes of SciVal data analysis have provided evidence-based understanding of the place that digital literacy takes in current comparative education discourse influenced by "shock digitisation". 
Table 1. Thematic blocks according to SciVal data for the keyword "digital literacy" for the period 2015-2020 (top-10)

\begin{tabular}{|c|c|c|c|c|c|}
\hline № & Topic & $\begin{array}{l}\text { Topic } \\
\text { Number }\end{array}$ & $\begin{array}{l}\text { Scholarly } \\
\text { Output }\end{array}$ & $\begin{array}{l}\text { Field-Weighted } \\
\text { Citation Impact }\end{array}$ & $\begin{array}{l}\text { Prominence } \\
\text { percentile }\end{array}$ \\
\hline 1 & Information Literacy; Library Instruction; Librarians & T.564 & 1926 & 0,63 & 96,459 \\
\hline 2 & Multiliteracies; Literacy Practices; New Literacies & T.12557 & 1322 & 1,12 & 94,136 \\
\hline 3 & $\begin{array}{l}\text { Mobile Money; Computer Supported Cooperative Work; Health } \\
\text { Auxiliary }\end{array}$ & T.13652 & 1131 & 0,9 & 95,004 \\
\hline 4 & Knowledge Organization; Paul Otlet; Library Science & T.14103 & 969 & 0,37 & 87,631 \\
\hline 5 & $\begin{array}{l}\text { Digital Divide; Internet Use; Information and Communication } \\
\text { Technology }\end{array}$ & T.19995 & 916 & 1,87 & 95,832 \\
\hline 6 & $\begin{array}{l}\text { European Higher Education Area; Mental Competency; Information } \\
\text { and Communication Technology }\end{array}$ & T.24895 & 568 & 0,74 & 89,712 \\
\hline 7 & Digital Natives; Millennials; Information Literacy & T.26023 & 443 & 0,65 & 84,429 \\
\hline 8 & Game-Based Learning; Video Games; Digital Literacies & T.22515 & 414 & 0,63 & 84,01 \\
\hline 9 & Media Literacy; Audiovisual Equipment; Digital Natives & T.31933 & 295 & 0,6 & 78,845 \\
\hline 10 & Library Services; Information Literacy; Contingent Valuation & T.29766 & 272 & 0,8 & 76,987 \\
\hline
\end{tabular}

Source: compiled by the authors using SciVal metrics

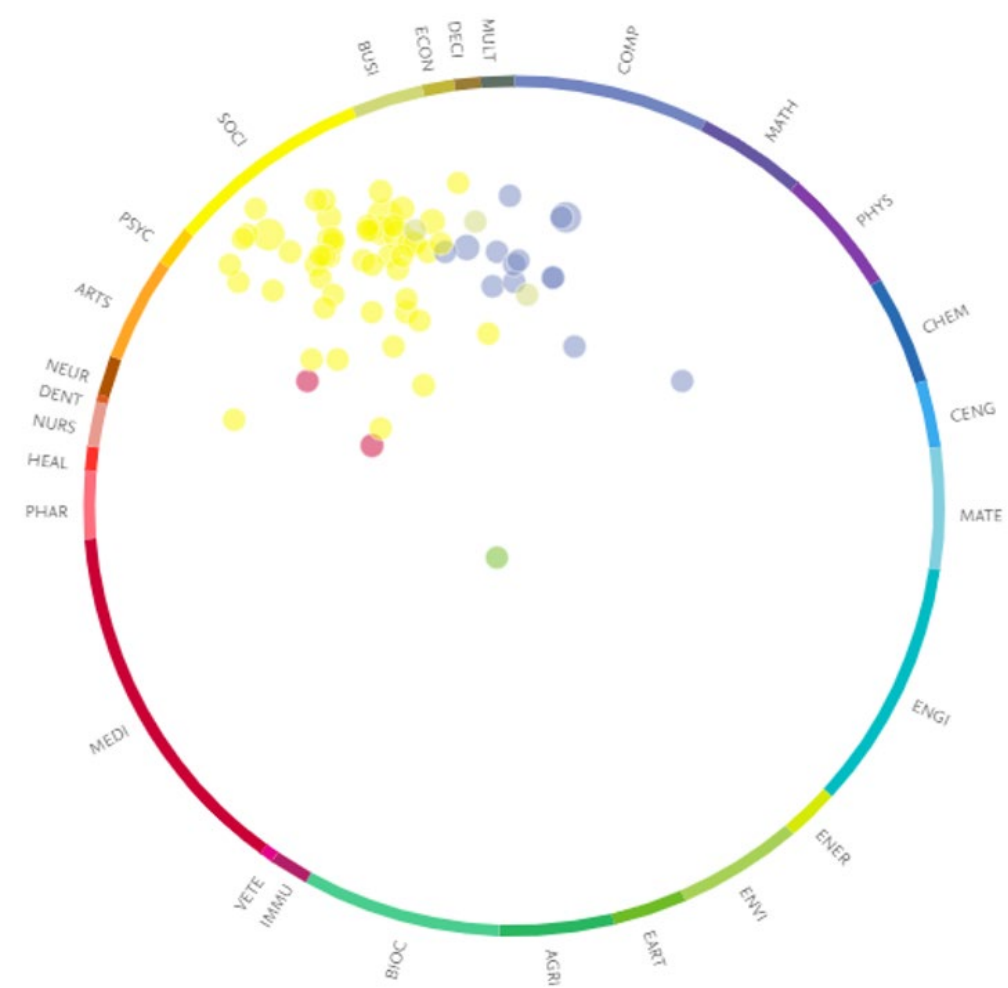

Figure 1. Distribution of topics of publications by the keyword "digital literacy" for the period 2015-2020 by fields of science Source: compiled by the authors using SciVal metrics.

\section{RESULTS}

\section{Digital Literacy Studies as a Key Trend of Today}

The notion of digital literacy was forged into concept and then introduced into scientific discourse in 1997 by Gilster (1997). At that period, it was understood as an "ability to understand and use information in multiple formats from a wide range of sources when it is presented via a computer" (Gilster, 1997, p. 1). It was later reconceptualized by several scholars who primarily tried to define the term, specify its essential attributes or develop the toolset for digital literacy assessment (Boronenko et al., 2019; Eshet-Alkalai, 2012). The number of concept interpretations is increasingly rising, with the essence of digital literacy being transformed to suit various sociocultural contexts. Recent years have witnessed the trend towards studying the phenomenon of digital literacy within the framework of social and professional traits. Thus, approaches to studying digital literacy have diversified regarding the age groups (old age people, adults, young adults, children), level of school and vocational training, family roles (children/parents), jobs. Some studies deal with digital literacy as a mechanism of social inclusion and access to government services.

Regardless the variety of issues considered by digital literacy studies (Table 1), social sciences prevail over other areas in terms of numbers and topical variety (Figure 1). 
Most publications in the sphere of education aim to find and describe distinctive features of digital literacy for learners. The definition of "digital literacy" is being further elaborated, along with the mechanisms of forming and developing digital literacy in key teaching/learning actors: schoolchildren, teachers, students.

Explanation of abbreviations used in Figure 1: COMP $=$ Computer Science; MATH = Mathematics; PHYS = Physics and Astronomy; CHEM = Chemistry; $\mathrm{CENG}=$ Chemical Engineering; MATE = Materials Science; ENGI = Engineering; ENER = Energy; ENVI = Environmental Science; $\mathrm{EART}=$ Earth and Planetary Sciences; AGRI = Agricultural and Biological Sciences; BIOC = Biochemistry, Genetics and Molecular Biology; IMMU = Immunology and Microbiology; VETE = Veterinary; MEDI = Medicine; PHAR = Pharmacology, Toxicology and Pharmaceutics; HEAL = Health Professions; NURS $=$ Nursing; DENT $=$ Dentistry; NEUR $=$ Neuroscience; ARTS $=$ Arts and Humanities; PSYC $=$ Psychology; SOCI $=$ Social Sciences; BUSI $=$ Business, Management and Accounting; ECON = Economics, Econometrics and Finance; DECI $=$ Decision Sciences; MULT = Multidisciplinary.

Some scholars concentrate on bridging the digital divide in school education systems of different countries (Quaicoe \& Pata, 2015). Secker (2012) presents a thorough analysis of the issue, highlighting personalized approach to developing researcher's digital literacy with due regard to the skills acquired, as well as the needs faced. Tsatsou (2018) goes deeper claiming that researchers' digital literacy relates not only to technical skills, but to emotions and social practices emerging in the process of harnessing technologies for research. Certain publications consider the crucial role of libraries in shaping digital literacy for research, as well as its increased importance in the context of Open Science that promotes open access to publications (Soltovets et al., 2020).

The concepts of digital literacy and illiteracy are gravely under considered in current scientific discourse. Digital literacy tends to be dealt with in terms of skills required for professional functioning, especially when the requirements are not met. The statement might be well illustrated with the study made by Cortina-Perez, et al. (2014). It analyses the roots of teachers' digital illiteracy. Among the reasons found were the following underlying factors:

- insufficient technical equipment;

- lack of teachers' awareness about the scope of available digital technologies for selfdevelopment;

- lack of skills and knowledge how to use digital technologies for teaching, as a result of conservative attitudes to digital media and poor confidence in the matter.
Surprisingly, no publications are currently exploring distinctive characteristics of researcher's digital illiteracy, though digital transformation has equally affected modern academic and scientific research environment. Despite the long-lasting research interest to digitisation of science, the entire spectrum of its impacts remains obscure. The impact of digitisation on the research process was described in detail by Meissner et al. (2016), who noted that the use of digital technologies in scientific activity is mainly reduced to data collection and its analysis, presentation of research findings and publications. Hence, researchers do not use the full scope of opportunities provided by digitisation and Open Science. At the same time, there are assumptions that the scientific community will gradually adapt to working in "digital" environment. The forced shift to distance format due to the spread of COVID-19 has ultimately accelerated the demand for digital science skills. This unprecedented challenge is left out of account.

\section{Digital Literacy of Comparative Education Researchers in SciVal Analytics}

Studies in various fields of social sciences account for $5.7 \%$ of all Scopus indexed publications, as it is seen from SciVal analytics of worldwide research within the period of 2015-2020 (Figure 2).

Most of the works published are education related (Figure 3).

The key topic clusters in social sciences include "education", "e-learning", "teacher-student" issues, "schooling" and some specific types of "literacy". Table 2 shows key topic clusters (top 50 topics) in social sciences. The title of "comparative education" falls under the topic T.20410 "Comparative Education; Educational Reform; UNESCO", with 77.960 topic prominence percentile, being part of the topic cluster ranking 31 in the top-50 list (Topic Cluster TC.150 Teacher; School; Education).

University College London, University of Bristol, Hong Kong Institute of Education, University of Cambridge, Kyoto University are among the most prominent institutions demonstrating high scholarly output of research in the field of comparative education (Table 3).

As far as Europe-based studies on the matter are concerned, one should note active contribution of scholars affiliated to the following institutions: University College London, University of Würzburg, University of Cambridge, Heidelberg University, University of Ljubljana, University of Florence, European University Institute, San Domenico di Fiesole, National Research Institute "Higher School of Economics" (Table 3). The only Russian higher education institution in in SciVal top 50 institutions leading in comparative education research field is 


\section{World is}

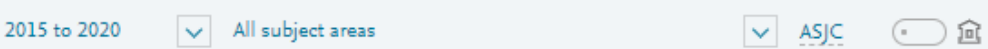

\section{Publications by Subject Area}

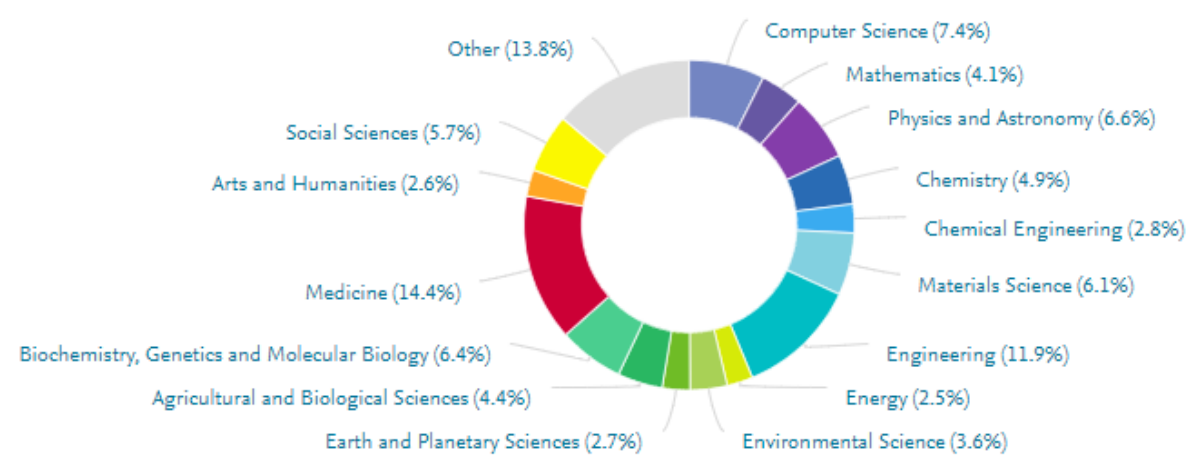

Figure 2. General distribution of publications in all subject areas for 2015-2020

Source: compiled by the authors using SciVal metrics

\section{Publications by Subject Area}

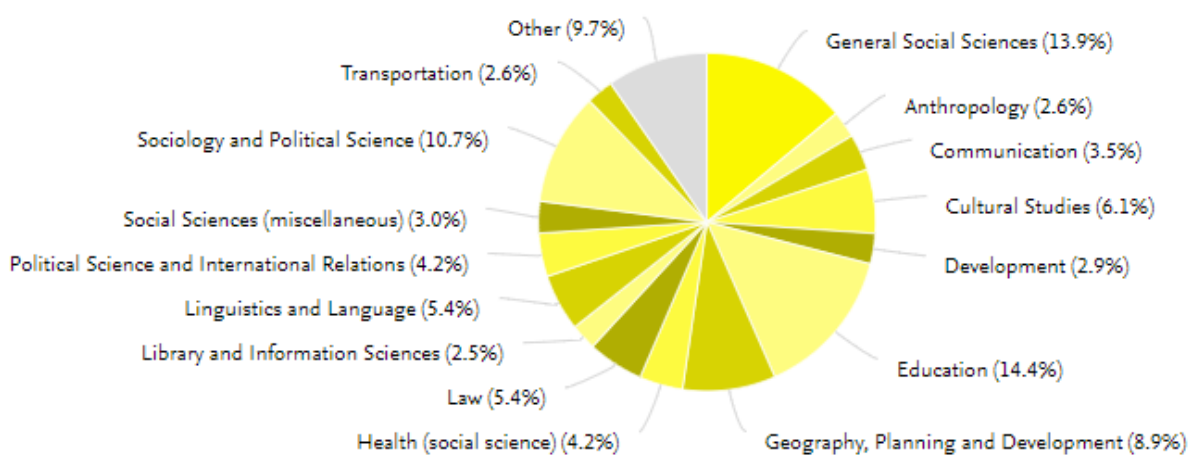

Figure 3. The main thematic areas in the social sciences for 2015-2020

Source: compiled by the authors using SciVal metrics

Table 2. Top-50 Topic Cluster in social sciences by prominence percentile, 2015-2020

\begin{tabular}{|c|c|c|c|c|c|}
\hline \multirow{2}{*}{ № } & \multirow{2}{*}{ Topic Cluster } & \multicolumn{2}{|c|}{ Topic Cluster Scholarly } & \multirow{2}{*}{$\begin{array}{l}\text { Field-Weighted } \\
\text { Citation Impact }\end{array}$} & \multirow{2}{*}{$\begin{array}{c}\text { Prominence } \\
\text { percentile }\end{array}$} \\
\hline & & Number & Output & & \\
\hline 1 & Electricity; Energy; Economics & TC.81 & 57401 & 1.38 & 99.264 \\
\hline 2 & Work; Personality; Psychology & TC.29 & 61662 & 1.08 & 97.858 \\
\hline 3 & Traffic Control; Transportation; Models & TC.107 & 54617 & 1.08 & 96.787 \\
\hline 4 & Child; Adolescent; Schools & TC.99 & 43137 & 1.16 & 95.114 \\
\hline 5 & Students; Medical Students; Education & TC.43 & 62655 & 0.91 & 94.378 \\
\hline 6 & Pervasive Child Development Disorders; Autistic Disorder; Child & TC.139 & 33427 & 1.11 & 94.244 \\
\hline 7 & Tourism; Tourists; Destination & TC.239 & 30140 & 0.98 & 90.964 \\
\hline 8 & Disasters; Floods; Risks & TC.438 & 24168 & 1.1 & 90.495 \\
\hline 9 & Students; Teaching; Education; E-Learning & TC.200 & 35876 & 1.1 & 89.893 \\
\hline 10 & Gambling; Internet; Students & TC.555 & 19780 & 1.45 & 89.826 \\
\hline 11 & Language; Reading; Semantics & TC. 88 & 32180 & 1.26 & 88.153 \\
\hline 12 & Morals; Research; Behavior & TC.267 & 26122 & 1.22 & 87.818 \\
\hline 13 & Publications; Periodicals As Topic; Research & TC.275 & 30189 & 0.81 & 87.617 \\
\hline
\end{tabular}

Source: compiled by the authors using SciVal metrics 
Table 2 (continued). Top-50 Topic Cluster in social sciences by prominence percentile, 2015-2020

\begin{tabular}{|c|c|c|c|c|c|}
\hline \multirow{2}{*}{ № } & \multirow{2}{*}{ Topic Cluster } & \multicolumn{2}{|c|}{ Topic Cluster Scholarly } & \multirow{2}{*}{$\begin{array}{l}\text { Field-Weighted } \\
\text { Citation Impact }\end{array}$} & \multirow{2}{*}{$\begin{array}{c}\text { Prominence } \\
\text { percentile }\end{array}$} \\
\hline & & Number & Output & & \\
\hline 14 & Media; News; Journalism & TC.279 & 29002 & 1.26 & 87.349 \\
\hline 15 & Wastes; Solid Wastes; Municipal Solid Waste & TC.703 & 14018 & 1.09 & 87.015 \\
\hline 16 & Party; Election; Voter & TC.172 & 38130 & 1.32 & 86.479 \\
\hline 17 & Violence; Women; Child & TC.310 & 21403 & 1.08 & 85.408 \\
\hline 18 & Roofs; Heat Island; Buildings & TC.622 & 14621 & 1.08 & 84.404 \\
\hline 19 & Ecosystem Services; Willingness To Pay; Valuation & TC.955 & 10665 & 1.31 & 83.668 \\
\hline 20 & Water; Water Resources; Water Management & TC.527 & 13777 & 1.1 & 81.392 \\
\hline 21 & Housing; Neighborhood; Gentrification & TC.281 & 22789 & 1 & 81.325 \\
\hline 22 & Transgendered Persons; Female Homosexuality; Bisexuality & TC.580 & 16622 & 1.3 & 79.719 \\
\hline 23 & Fossils; Pleistocene; Paleolithic & TC.127 & 18937 & 1.26 & 79.518 \\
\hline 24 & Offense; Police; Offender & TC.207 & 24634 & 1.24 & 79.451 \\
\hline 25 & Research; Technology; Industry & TC.637 & 14602 & 1.26 & 79.384 \\
\hline 26 & Teachers; Language; Student & TC.265 & 28423 & 1.26 & 78.581 \\
\hline 27 & Vehicles; Accident Prevention; Highway Accidents & TC.315 & 19884 & 0.79 & 78.38 \\
\hline 28 & Forest; Deforestation; Conservation & TC.663 & 12268 & 1.23 & 77.845 \\
\hline 29 & Students; Russian; Education & TC.1114 & 20851 & 1.04 & 77.644 \\
\hline 30 & Sports; Students; Athletes & TC.443 & 16552 & 1.06 & 77.175 \\
\hline 31 & Teacher; School; Education & TC.150 & 28528 & 0.98 & 76.64 \\
\hline 32 & Food; Consumers; Farmers & TC.437 & 14525 & 0.92 & 76.238 \\
\hline 33 & Students; Science; Learning & TC.230 & 24615 & 0.9 & 75.234 \\
\hline 34 & Health Literacy; Patients; Internet & TC.717 & 14831 & 1.12 & 73.762 \\
\hline 35 & Students; Education; Teaching & TC.542 & 15921 & 1.04 & 73.494 \\
\hline 36 & Nurses; Nursing; Students & TC.212 & 19420 & 0.94 & 71.954 \\
\hline 37 & Watersheds; Soil Erosion; Catchments & TC.476 & 10542 & 1.02 & 70.75 \\
\hline 38 & Criminals; Violence; Mental Health & TC.388 & 12556 & 0.83 & 69.478 \\
\hline 39 & Mathematics; Students; Teacher & TC.391 & 18529 & 0.97 & 69.076 \\
\hline 40 & Vehicle Routing; Algorithms; Vehicles & TC.931 & 8911 & 1.02 & 69.009 \\
\hline 41 & Microfinance; Farmers; Cooperative & TC.532 & 12903 & 0.84 & 68.407 \\
\hline 42 & Science; Risks; Nanotechnology & TC. 550 & 11361 & 1.22 & 67.738 \\
\hline 43 & Emigrants And Immigrants; Hispanic Americans; Acculturation & TC.646 & 11769 & 1.08 & 67.269 \\
\hline 44 & Buildings; Design; Urban Planning & TC.857 & 11240 & 0.88 & 66.801 \\
\hline 45 & Research; Clinical Trials As Topic; Patients & TC.463 & 13453 & 0.94 & 66.734 \\
\hline 46 & Students; Teacher; Learning & TC.337 & 16084 & 0.92 & 66.6 \\
\hline 47 & Human Engineering; Ergonomics; Automation & TC.588 & 11954 & 1.09 & 66.332 \\
\hline 48 & Research; Science; Periodicals As Topic & TC.932 & 8126 & 1.88 & 66.265 \\
\hline 49 & Child; Geography; Research & TC.596 & 17430 & 0.97 & 66.198 \\
\hline 50 & $\begin{array}{l}\text { Photogrammetry; Unmanned Aerial Vehicles (UAV); Remote } \\
\text { Sensing }\end{array}$ & TC.972 & 10522 & 1.16 & 65.529 \\
\hline
\end{tabular}

Source: compiled by the authors using SciVal metrics

Table 3. Top-50 institutions with faculty doing research in comparative education

\begin{tabular}{|c|c|c|c|c|c|}
\hline № & Institution & $\begin{array}{l}\text { Scholarly } \\
\text { Output }\end{array}$ & $\begin{array}{l}\text { Views } \\
\text { Count }\end{array}$ & $\begin{array}{l}\text { Field-Weighted } \\
\text { Citation Impact }\end{array}$ & $\begin{array}{c}\text { Citation } \\
\text { Count }\end{array}$ \\
\hline 1 & University College London & 12 & 124 & 0.5 & 18 \\
\hline 2 & University of Bristol & 12 & 157 & 2.47 & 54 \\
\hline 3 & Hong Kong Institute of Education & 9 & 127 & 1.72 & 22 \\
\hline 4 & University of Cambridge & 9 & 94 & 3.67 & 94 \\
\hline 5 & Kyoto University & 8 & 80 & 5.4 & 84 \\
\hline 6 & University of Sydney & 8 & 91 & 2.44 & 85 \\
\hline 7 & Loyola University Chicago & 6 & 46 & 0.68 & 23 \\
\hline 8 & Monash University & 6 & 20 & 0 & 0 \\
\hline 9 & North West University & 6 & 31 & 0.43 & 2 \\
\hline 10 & University of New England & 6 & 65 & 3.19 & 94 \\
\hline 11 & Columbia University & 5 & 49 & 0.65 & 12 \\
\hline 12 & The University of the West Indies & 5 & 30 & 0.06 & 2 \\
\hline 13 & University of Glasgow & 5 & 42 & 2.02 & 9 \\
\hline 14 & University of Maryland, College Park & 5 & 44 & 6.45 & 26 \\
\hline 15 & University of Nottingham & 5 & 30 & 0.2 & 4 \\
\hline 16 & University of Würzburg & 5 & 37 & 1.24 & 2 \\
\hline 17 & Arizona State University & 4 & 43 & 2.32 & 29 \\
\hline 18 & Australian Catholic University & 4 & 28 & 0.66 & 3 \\
\hline
\end{tabular}

Source: compiled by the authors using SciVal metrics 
Table 3 (continued). Top-50 institutions with faculty doing research in comparative education

\begin{tabular}{|c|c|c|c|c|}
\hline № Institution & $\begin{array}{l}\text { Scholarly } \\
\text { Output }\end{array}$ & $\begin{array}{l}\text { Views } \\
\text { Count }\end{array}$ & $\begin{array}{l}\text { Field-Weighted } \\
\text { Citation Impact }\end{array}$ & $\begin{array}{c}\text { Citation } \\
\text { Count }\end{array}$ \\
\hline 19 The University of Auckland & 4 & 28 & 3.28 & 29 \\
\hline 20 University of Melbourne & 4 & 11 & 0.55 & 2 \\
\hline 21 University of the Western Cape & 4 & 16 & 0.08 & 3 \\
\hline 22 University of Toronto & 4 & 29 & 0.72 & 13 \\
\hline 23 University of Wisconsin-Madison & 4 & 29 & 3.2 & 33 \\
\hline 24 Australian National University & 3 & 7 & 0.07 & 3 \\
\hline 25 Deakin University & 3 & 26 & 0.84 & 4 \\
\hline 26 Durham University & 3 & 18 & 3.04 & 8 \\
\hline 27 Heidelberg University & 3 & 10 & 0.47 & 5 \\
\hline 28 Higher School of Economics & 3 & 83 & 0.33 & 5 \\
\hline 29 Queensland University of Technology & 3 & 18 & 0.84 & 4 \\
\hline 30 SOAS University of London & 3 & 19 & 0 & 0 \\
\hline 31 The University of Hong Kong & 3 & 120 & 3.71 & 33 \\
\hline 32 Universidade de São Paulo & 3 & 52 & 0.05 & 1 \\
\hline 33 University of British Columbia & 3 & 11 & 0.44 & 2 \\
\hline 34 University of Calgary & 3 & 19 & 0.09 & 2 \\
\hline 35 University of Edinburgh & 3 & 35 & 0.69 & 6 \\
\hline 36 University of Florence & 3 & 14 & 2.07 & 2 \\
\hline 37 University of Johannesburg & 3 & 34 & 1.09 & 15 \\
\hline 38 University of Ljubljana & 3 & 13 & 0.1 & 1 \\
\hline 39 University of Minnesota Twin Cities & 3 & 32 & 1.02 & 25 \\
\hline 40 University of Pittsburgh & 3 & 34 & 0.07 & 1 \\
\hline 41 Western Norway University of Applied Sciences & 3 & 21 & 0.16 & 5 \\
\hline 42 Brigham Young University & 2 & 24 & 1.28 & 4 \\
\hline 43 Charles Sturt University & 2 & 12 & 2.28 & 2 \\
\hline 44 Consejo Nacional de Investigaciones Científicas y Técnicas & 2 & 14 & 0 & 0 \\
\hline 45 Edge Hill University & 2 & 15 & 0.82 & 9 \\
\hline 46 European University Institute, San Domenico di Fiesole & 2 & 1 & 1.05 & 3 \\
\hline 47 Florida Atlantic University & 2 & 6 & 0.33 & 2 \\
\hline 48 Georgia State University & 2 & 11 & 0.33 & 2 \\
\hline 49 Griffith University Queensland & 2 & 26 & 0.72 & 5 \\
\hline 50 Huazhong University of Science and Technology & 2 & 10 & 0.11 & 1 \\
\hline
\end{tabular}

Source: compiled by the authors using SciVal metrics

Higher School of Economics which ranks 28. The publications of scholars affiliated to the British universities are numerous enough to suggest an outstanding contribution of the UK researchers to the domain.

The analysis of publication performance in the areas related to digital literacy has revealed two topical trends among the publications presented in SciVal analytics as indexed within the period of 2015-2020. Digital literacy tends to be tackled either instrumentally, as an integral part of computer-assisted processes in professionally driven issues research, or as a component of students' development mechanism (Figure 4).

The cloud of key phrases related to the cluster $\mathrm{T}$. 76725 Digital Literacy; Knowledge Society; Learning Communities shows the shift of the research focus towards digitisation of industrial/vocational and educational environment with apparent gaps in publications related to researchers' digital literacy (Figure 5).

Comparative education terrain also seems poorly studied in terms of direct digitisation impact, according to the "key words" analysis. A clear turn to the issues of practical or technical nature is seen in the scope of publications within the cluster.

The issues of digital literacy in education have been actively studied by the scholars from Spanish, American, British, Australian and Chinese universities, as demonstrated by Figure 6.

The total number of Europe-based research publications indexed in Scopus database in cluster $\mathrm{T}$. 76725 Digital Literacy; Knowledge Society; Learning Communities can clearly evidence the precedence of European "rival" scholars in comparative aspects of digital literacy exploration (Figure 7).

It is worth noting that most publications considering educational and institutional aspects of digital literacy have been authored by British, as well as Spanishspeaking scholars, as evidenced by the total scholarly output and field-weighted citation impact.

However, an important constraint is that the works of the mentioned scholars fail to tackle a comparative aspect in digital literacy. The SciVal metrics analysis also revealed the lack of works on the topics of digital literacy within the framework of Open Science phenomenon, especially the issues of modern researchers' digital 


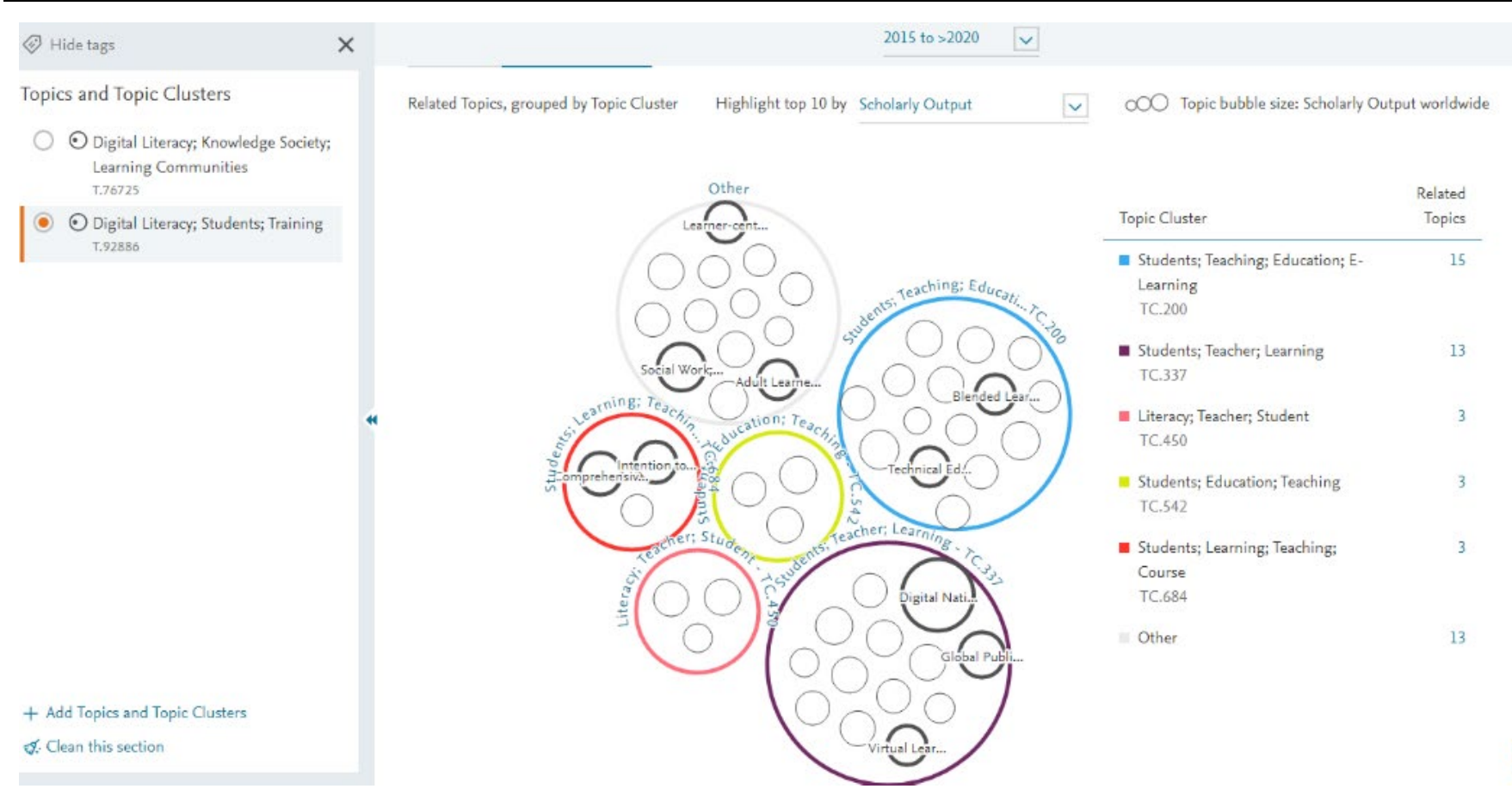

Figure 4. Trends in the subjects of publications in the cluster T. 92886 Digital literacy; Students; Training for the period 2015-2020

Source: compiled by the authors using SciVal metrics

2015 to $>2020$

\section{Topic character}

\footnotetext{
- Keyphrase analysis $\bigcirc$ Representative publications

Top 50 keyphrases by relevance, based on 33 publications | Learn about keyphrase calculations $\lambda$
}

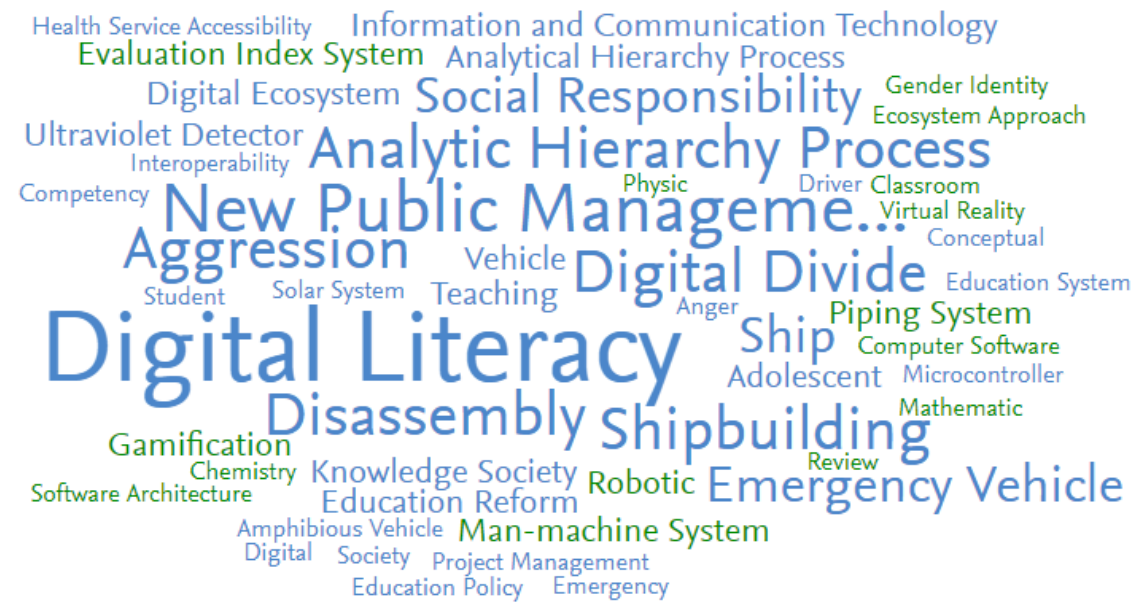

A A A relevance of keyphrase | declining A A A growing (2015-2019)

Figure 5. Analysis of trends in publication activity in the cluster T. 92886 Digital literacy; Students; Training based on the frequency of use of key phrases for the period 2015-2020

Source: compiled by the authors using SciVal metrics 


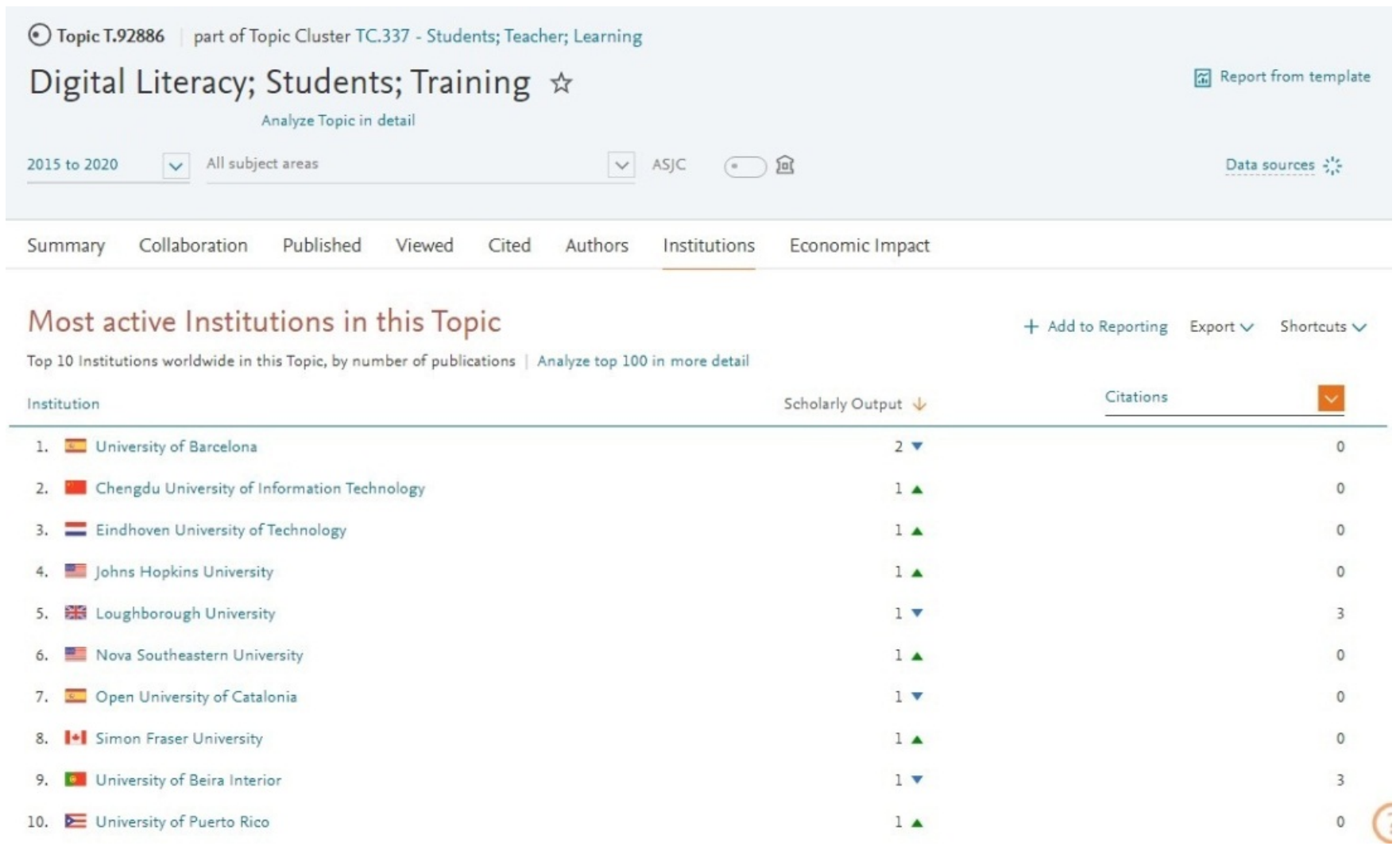

Figure 6. Ranking of universities by the number of publications on the topic of digital literacy for the period 2015-2020 Source: compiled by the authors using SciVal metrics

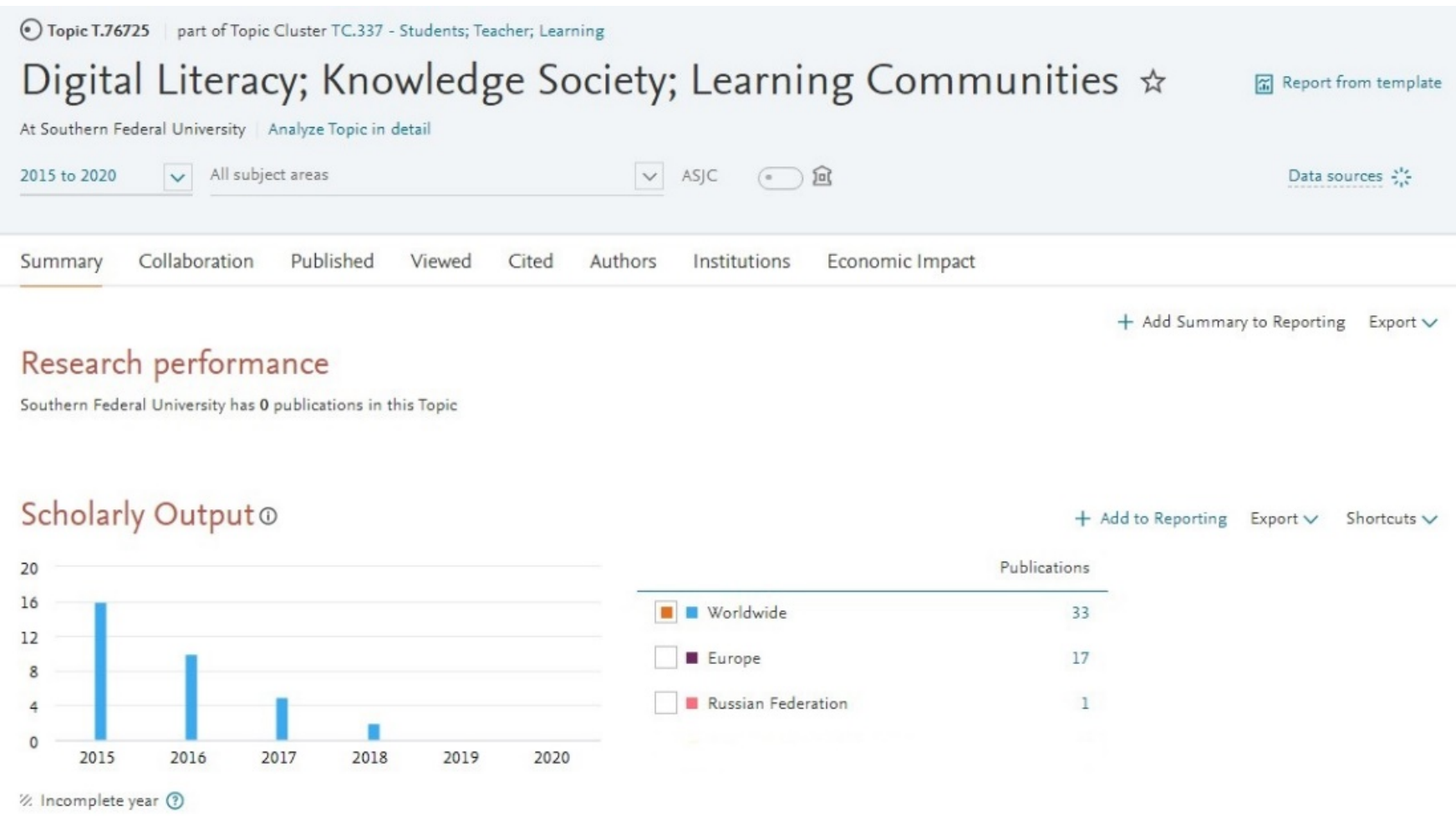

Figure 7. The number of European and Russian studies in the cluster T. 76725 Digital Literacy; Knowledge Society; Learning Communities 2015-2020

Source: compiled by the authors using SciVal metrics 
literacy. Few publications in the represented cluster may be accounted for the fact that the authors selecting key words for their articles give no due regard to the clusterrelated key words recommended by SciVal.

\section{DISCUSSION}

Digitisation is a multidimensional phenomenon affecting directly and indirectly all spheres of human activity. Its intermediate impact on education and science requires a profound rethinking of the assumptions and agenda priorities in a number of issues: general requirements for the modern researcher's qualification, requirements to research procedures, the level of functional and digital literacy of a scientist, changes in research career potentials and prospects. However, relative smoothness and predictability of digitalization has hardly helped the academia to adapt to current global challenges, such as the COVID-19 pandemic. This is noted by many researchers, in particular Tejedor et al. (2020), Edelmann and Schoßböck (2020), and Martzoukou (2020).

Noteworthy that priority is given to the issues of urgent practicalities, while systemic transformations in the field of science have not yet enjoyed sufficient consideration, which is also emphasized in research works by Popova (2019), and Pogorelova and Efimova (2020). With the dizzying speed of socio-economic changes that have swept the world in the last year it is obvious we are dealing with digitisation of shock, rather than phased, character.

"Shock digitisation" contributed to the emergence of the need for the formation and development of new skills for functioning in the modern society. In this regard, the interest of researchers in the phenomenon of "digital literacy" is increasing in modern scientific discourse (Boronenko et al., 2019; Sánchez-Cruzado et al., 2021). Digital literacy being a new type of the XXI century literacy has become a complex phenomenon characterizing various "life" or "soft" skills necessary to operate in the growing digital environments. Studies on comparative education, which describe the experience of different countries in the field of digitalization, are of particular value for understanding digital literacy at the present stage. In most of these studies, the problems of the formation of digital literacy in schoolchildren, students, and teachers are considered. However, the digital literacy gaps of researchers remain a poorly understood and problematic area. As the organizational and methodological research frameworks are being transformed in a new digital environment, the need to rethink and update professional skills for quality research is increasingly felt. Our idea is also supported by Meissner et al. (2016) who point that the Intensive technological environment and high interest in Big Data led to a rapid increase of demand for digital researcher skills.

\section{CONCLUSION}

Currently, the need for the digital transformation of science and education is considerably mainstreamed both at the government level and at the level of scientific communities and associations. Nevertheless, the issues of digital illiteracy of comparative education researchers remain an underexplored and problematic area of education studies. The gaps in digital literacy of researchers used to play the role of general constraint to global science development. Digital literacy is currently growing in significance as an absolute prerequisite of a scientist claiming to be functionally efficient in the global academic environment. It should also be emphasized that the professional activity of a comparative education researcher affects the development of the next generation researchers and science. The quality of research in the field of education achieved through methodological accuracy plays an important role for scientific progress in general and the development of the scientific human capacity in particular. Further research in the field is required as it may facilitate consolidation of comparative education experts' and practitioners' opinions, thus summarizing approaches to tackling the problem of digital illiteracy of comparative education researcher. Such studies might potentially mitigate the consequences of "shock digitisation" in Open Science and improve the quality of research in the field of comparative education.

Author contributions: All authors have sufficiently contributed to the study, and agreed with the results and conclusions.

Funding: No funding source is reported for this study.

Declaration of interest: No conflict of interest is declared by authors.

\section{REFERENCES}

Boronenko, T. A., Kaisina, A. V., \& Fedotova, V. S. (2019). The Development of digital literacy of schoolchildren in conditions of creating a digital educational environment. Perspectives of Science and Education, 2(38), 167-193. https:/ / doi.org/10.32744 /pse.2019.2.14

Chigisheva, O. P. (2018). Researcher`s digital literacy in Open Science. Azimuth of Scientific Research: Pedagogy and Psychology, 7(4), 241-244. http:/ / anipp .ru/wp-content/uploads/2021/02/ ANI-PiP-2018425.pdf

Cortina-Pérez, B., Gallardo-Vigil, M. Á., JiménezJiménez, M. Á., \& Trujillo-Torres, J. M. (2014). Digital illiteracy: a challenge for 21st century teachers. Cultura y Educacion, 26(2), 231-264. https:/ / doi.org/10.1080/11356405.2014.935108

Edelmann, N., \& Schoßböck, J. (2020). Open access perceptions, strategies, and digital literacies: A case study of a scholarly-led journal. Publications, 8(3), Article No 44. https://doi.org/10.3390/publica tions 8030044 
Eshet-Alkalai, Y. (2012). Thinking in the digital era: a revised model for digital literacy. Issues in Informing Science and Information Technology, 9, 267-276. https://doi.org/10.28945/1621

European Charter for Researchers - The Code of Conduct for the Recruitment of Researchers. (2005). https://www.um.si/en/research/human_resourc es/Documents/The \%20European \%20Charter \% 20f or\%20Researchers.pdf

Galchenko, N. A., Shatskaya, I. I., Makarova, E. V., Kulesh, E. V., Nizamutdinova, S. M., Yudina, A. M. \& Skutelnik, O. A. (2020). Student hood spiritual needs in self-isolation period: Features and ways to meet them. EurAsian Journal of BioSciences, 14(1), 2229-2234.

Gilster, P. (1997). Digital literacy. Wiley Computer Publications. https://www.worldcat.org/title/ digital-literacy/oclc/35758248

Gimaliev, V. G., Prokopyev, A. I., Vershinin, V. P., Ivanova, M. E., Erkibaeva, G. G., Aytuganova, J. I., \& Alexandrova, N. S. (2020). Public relations in organizations in student view: Accumulator of management tools or formation of partnership and friendly relations. Journal of Environmental Treatment Techniques, 8(4), 1326-1330. https:/ / doi.org/10.47277/JETT/8(4)1230

Ivanova, S. V., \& Ivanov, O. B. (2020). Education in the era of the fourth industrial revolution: development vector, prospects and challenges for Russia. Space and Culture, India, 7(5), 70-79. https:// doi.org/10.20896/saci.v7i5.703

Kvon, G. M., Vaks, V. B., Masalimova, A. R., Kryukova, N. I., Rod, Y. S., Shagieva, R. V., \& Khudzhatov, M. B. (2018). Risk in implementing new electronic management systems at universities. Eurasia Journal of Mathematics, Science and Technology Education, 14(3), 891-902. https://doi.org/10.12973 / ejmste/81060

Leifert, C. L., Schulze, M., \& Stojanovic Gajic, S. (2020). Cybersecurity for think tanks part one: Shock digitisation. https://onthinktanks.org/articles/ cybersecurity-for-think-tanks-part-one-shockdigitisation/

Levina, I. D., Ukolova, L. I., Lavrentyeva, E. Y., Akhilgova, M. T., Zharikov, Y. S., Popova, O. V., Semyanov, E. V., Malanov, I. A., Muskhanova, I. V., Magomeddibirova, Z. A., Bazaeva, F. U., \& Isaeva M. A. (2019). Nursing home conditions for elderly people and its peculiarities of their adaptation. EurAsian Journal of BioSciences, 13(2), 1549-1555.

Martzoukou, K. (2020). Academic libraries in COVID-19: a renewed mission for digital literacy. https://rgurepository.worktribe.com/OutputFile/977779

Meissner, D., Narkhova, A., \& Plekhanov, D. (2016). The meaning of digitalization for research skills: Challenges for STI policy. https://doi.org/10.2139/ssrn. 2857133

Pogorelova, E. V., \& Efimova, T. B. (2020). Digital transformation of education, science and innovations. Lecture Notes in Networks and Systems, 84, 54-61. https://doi.org/10.1007/978-3-03027015-5_7

Popova, S. M. (2019). To the question of the notion of digital transformation of science. Trends and Management, 4, 1-16. https://doi.org/10.7256/ 2454-0730.2019.4.31941

Potapova, S. V., Danilova, I. Y., Prasolov, V. I., Makarova, E. V., \& Kryukova, N. I. (2018). Mythological foundations of ontology. XLinguae, 11(2), 672-685. https://doi.org/10.18355/XL.2018. 11.02 .53

Quaicoe, J. S., \& Pata, K. (2015). The teachers' digital literacy: determining digital divide in public basic schools in Ghana. Communications in Computer and Information Science, 552, 154-162. https: / / doi.org/10.1007/978-3-319-28197-1_16

Research Metrics Guidebook. (2019). https://www. elsevier.com/research-intelligence/resourcelibrary/research-metrics-guidebook

Sánchez-Cruzado, C., Santiago Campión, R., \& SánchezCompaña, M. T. (2021). Teacher digital literacy: the indisputable challenge after covid-19. Sustainability (Switzerland), 13(4), Article No 1858. https:/ / doi.org/10.3390/su13041858

Secker, J. (2012). Digital literacy support for researchers: the personalised approach. In A. Priestner, E. Tilley (Eds.), Personalising library services in higher education: the boutique approach (pp. 107-125). Routledge. http:/ / eprints.lse.ac.uk/45810/

Shinkevich, M. V., Mashkin, N. A., Ishmuradova, I. I., Kolosova, V. V., \& Popova, O. V. (2020). Management of sustainable consumption of energy resources in the conditions of digital transformation of the industrial complex. International Journal of Energy Economics and Policy, 10(5), 454-460. https://doi.org/10.32479/ijeep. 10202

Soltovets, E., Chigisheva, O., \& Dmitrova, A. (2020). The role of mentoring in digital literacy development of doctoral students at British Universities. Eurasia Journal of Mathematics, Science and Technology Education, 16(4), em1839. https://doi.org/10.29333 /ejmste/117782

Soltovets, E., Chigisheva, O., Dubover, D., \& Dmitrova, A. (2021). Russian digital education landscape during the current pandemic: is the impact felt? E3S Web of Conferences, 273, 12026. https:/ / doi.org/10.1051/e3sconf/202127312026

Tejedor, S., Cervi, L., Pérez-Escoda, A., \& Jumbo, F. T. (2020). Digital literacy and higher education during 
COVID-19 lockdown: Spain, Italy, and Ecuador. Publications, 8(4), Article No 48. https://doi.org/ $10.3390 /$ publications 8040048

Toffler, A. (1971). Future shock. Bantam Books. https:// www.worldcat.org/title/future-shock/ oclc/761396886

Tsatsou, P. (2018). Literacy and training in digital research: researchers' views in five social science and humanities disciplines. New Media and Society, 20(3), 1240-1259. https:/ / doi.org/10.1177/1461444 816688274

Tugun, V., Bayanova, A. R., Erdyneeva, K. G., Mashkin N. A., Sakhipova, Z. M., \& Zasova, L. V. (2020). The opinions of technology supported education of university students. International Journal of Emerging Technologies in Learning, 15(23), 4-14. https:/ / doi.org/10.3991/ijet.v15i23.18779

Yermilova, V. V., Loktionova, Y. N., Smirnov, A. V., Seregina, T. N., \& Prokopyev, A. I. (2019). The development of a personal wellbeing index indicator of the life satisfaction. Espacios, 40(25), Article number 16.

Zyubina, I. A., Dzyubenko, A. I., Borisenko, V. A., Popova, O. V., \& Prokopyev, A. I. (2019). Implicit linguopragmatic strategies of speech behavior of English-speaking prosecutors. XLinguae, 12(4), 92102. https:/ / doi.org/10.18355/XL.2019.12.04.08

http://www.ejmste.com 